\title{
APPLICATION OF ELECTROCOAGULATION FOR WATER CONDITIONING
}

\author{
Hana Posavčić ${ }^{* *}$, Ivan Halkijević1 ${ }^{\text {Živko Vuković }}{ }^{1}$ \\ ${ }^{1}$ Faculty of Civil Engineering, University of Zagreb, Kačićeva 26, 10000 Zagreb \\ *E-mail of corresponding author: hposavcic@grad.hr
}

\begin{abstract}
Water conditioning is a method of removing altering minerals, chemicals and contaminants from a water source and it is carried out on facilities equipped with the corresponding electro-mechanical equipment. Although efficient, conventional processes typically use several complex devices connected to a single functional unit, which are often expensive to maintain and occupy large areas. Therefore, the aim of this paper is to present the electrocoagulation (EC) method as an alternative to conventional water conditioning processes. The examples of previous studies of the EC process application is presented in this paper. The focus of the paper is to investigate the influence of the certain operational parameters such as $\mathrm{pH}$, temperature, electrode material, etc., on the efficiency of pollutant removal such as Escherichia coli and elevated concentrations of iron, arsenic, manganese, ammonia and others. Further, an economic analysis is made, which, from an economic point of view, shows when it is feasible to use the EC in the conditioning process. Furthermore, a case study of electrocoagulation process for Total Nitrogen (TN) removal is presented. According to results, $69.7 \%$ of TN was removed with aluminum electrodes after 240 minutes. For this case, total operating costs were $7.60 \mathrm{\epsilon} / \mathrm{m}^{3}$.
\end{abstract}

Keywords: electrocoagulation, water conditioning, operative parameters, total nitrogen

\begin{tabular}{c}
\hline $\begin{array}{c}\text { Received: } 27.06 .2019 . / \text { Accepted: 18.11.2019. } \\
\text { Published online: 09.12.2019. }\end{array}$ \\
Original scientific paper
\end{tabular}

\section{INTRODUCTION}

Access to clean drinking water is a basic human right. According to the Council Directive 98/83/EC (Official Journal L 330) on the quality of water intended for human consumption, drinking water shall be wholesome and clean if it is free from any micro-organisms, parasites and substances which in numbers or concentrations constitute a potential danger to human health, whereby must meet minimum requirements regarding microbiological and chemical properties, radioactivity and physical properties.

In case of unsatisfactory values of certain parameters established by the Council Directive 98/83/EC (Official Journal L 330), appropriate activities shall be undertaken to ensure the quality of the water and, where necessary, to prohibit or limit the use of the water. Water conditioning is a method of removing altering minerals, chemicals and contaminants from a water source and it is carried out on facilities equipped with the corresponding electromechanical equipment (Vuković 2017).

According to (Croatian Institute of Public Health 2018) in $69 \%$ of water supply areas water is not processed before the distribution to the consumers. In the remaining $31 \%$ of water supply areas, the water is treated, dominating the filtration process, and a combination of aeration and filtration, a combination of filtration, coagulation, flocculation and precipitation, and manganese and/or iron removal are also used (Figure 1). Although efficient, conventional processes typically use several complex devices connected to a single functional unit, which are often expensive to maintain and occupy large areas. Therefore, the aim of this paper is to present the electrocoagulation (EC) method as an alternative to conventional water conditioning processes.

Furthermore, (Croatian Institute of Public Health 2018) analyzed the quality of water for human consumption and stated that the most common cause of its malfunction is the presence of Escherichia coli (E. coli) and total coliforms, as well as the elevated concentrations of iron, arsenic, manganese, ammonia, color, smell and turbidity. Therefore, the focus of the paper is to investigate the influence of the certain operational parameters such as $\mathrm{pH}$, temperature, electrode material, etc., on the efficiency of removing the mentioned contaminants.

An economic analysis is also made, which, from an economic point of view, shows when it is feasible to use $\mathrm{EC}$ in the conditioning process.

Additionally, the influence on total nitrogen removal efficiency was evaluated for some of the process parameters on a full-scale EC unit. For this specific case, operating costs are also determined. 


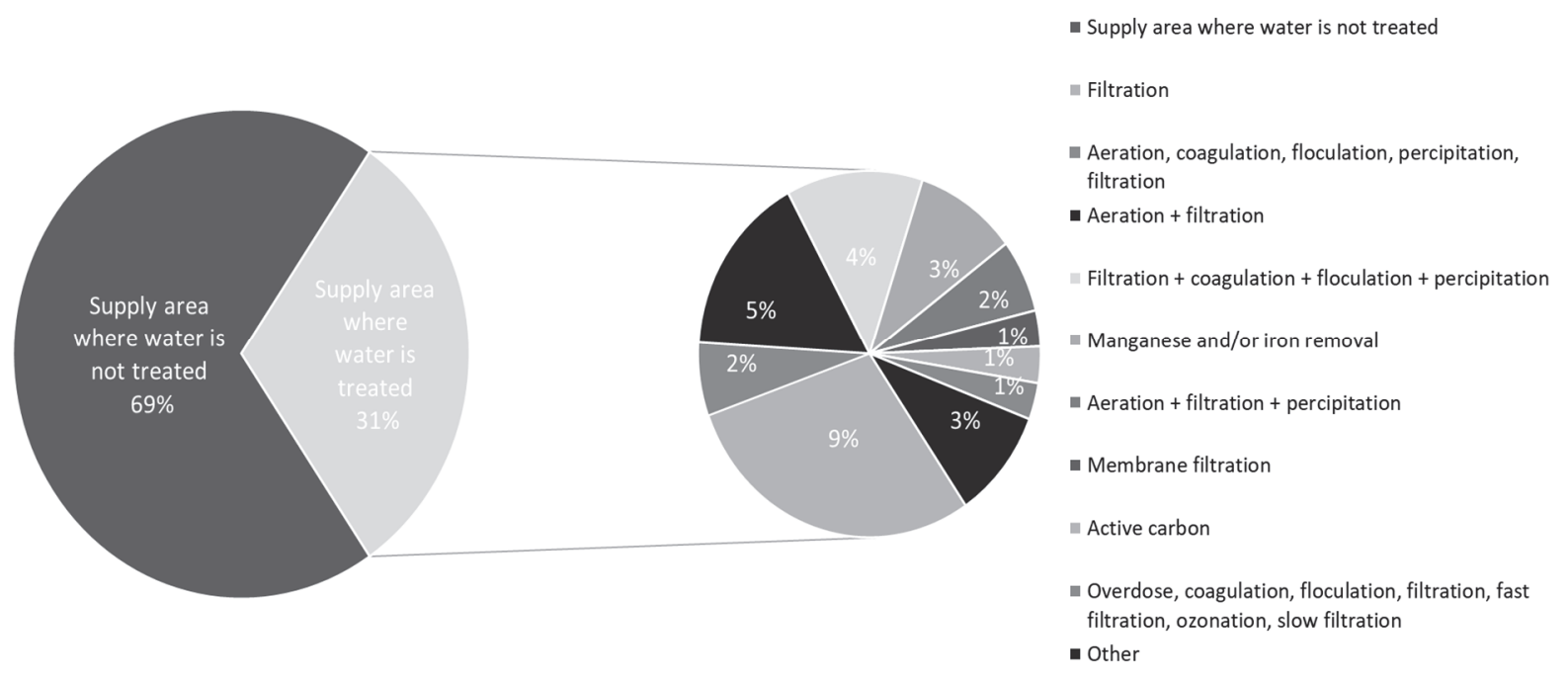

Figure 1. Water conditioning technologies (Croatian Institute of Public Health, 2018)

\section{THEORY OF ELECTROCOAGULATION}

The EC process, Figure 2, combines the benefits of coagulation, flotation or precipitation and electrochemistry (Moussa 2017). It includes coagulation and precipitation of pollutants (suspended solids and solutes) from the wastewater by the use of electricity and sacrificing electrodes for the "in situ" coagulant production (Gardic 2007). In the EC reactor, the wastewater flows between electrodes while the direct current is applied to them. Electrodes are usually made of metal, mostly iron (Fe) or aluminum (Al), because these materials are cheap, available, nontoxic and proven effective. The choice of electrode material and the arrangement of electrodes depend on the wastewater contamination and the required effluent quality. Usually, aluminum is used for the drinking water treatment and iron for the wastewater treatment (Chen and Hung 2007; Shammas et al. 2010; Kuokkanen et al. 2013; Hakizimana 2017).

\section{ELECTROCOAGULATION}

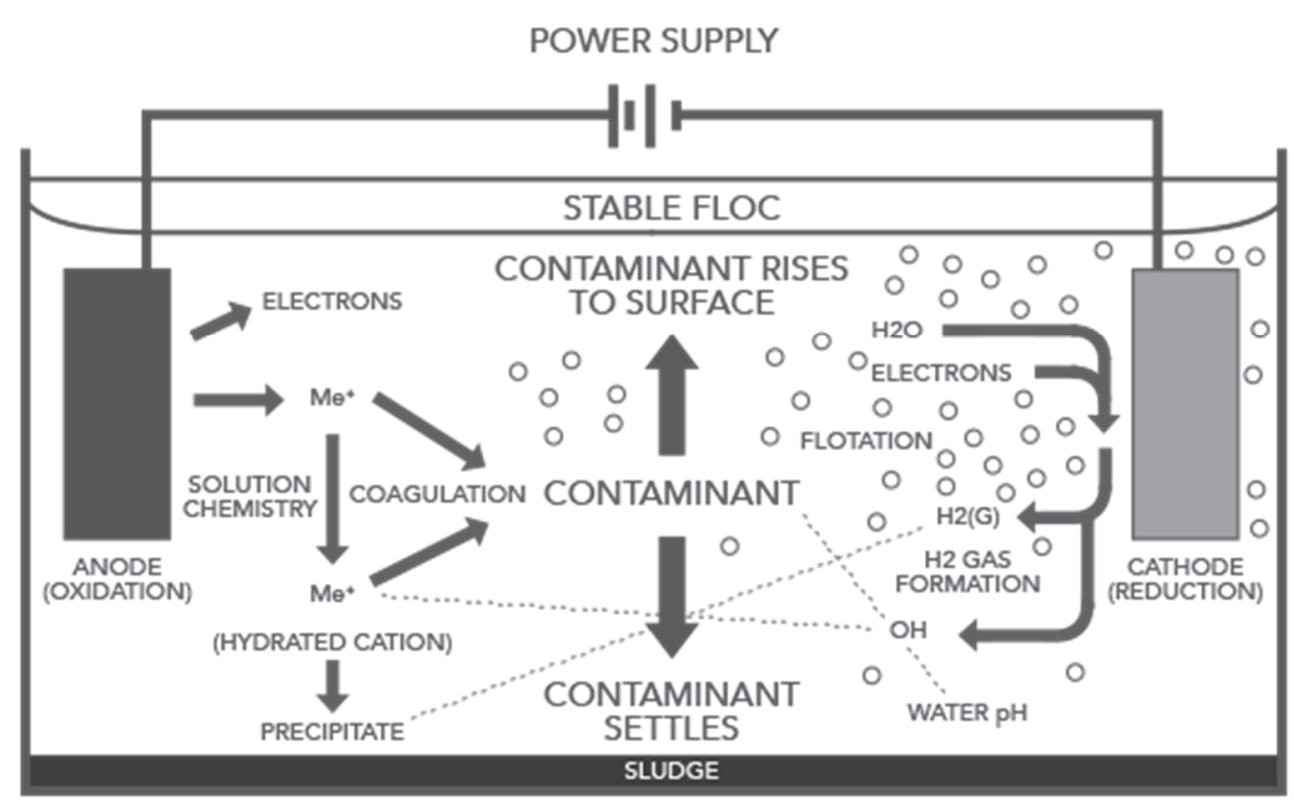

Figure 2. Electrocoagulation process

(https://www.crs-reprocessing.com/en/crs-solutions/electrocoagulation/, Accessed March 11 2019) 
According to the Equation 1, when the current is passed through metal electrode, the metal (M) from the anode is oxidized to its cations $\left(\mathrm{M}^{\mathrm{n}+}\right)$. Simultaneously, water is reduced to hydrogen gas and the hydroxide ion $\left(\mathrm{OH}^{-}\right) \mathrm{On}^{-}$ the cathode (Equation 2) (Kabdaşli et al. 2012):

$$
\begin{aligned}
& M \rightarrow M^{n+}+n e^{-} \\
& 2 H_{2} O(l)+2 e^{-} \rightarrow H_{2}(g)+2 O H^{-}(a q)
\end{aligned}
$$

By forming monomeric and polymeric hydroxides, metal cations $\left(\mathrm{M}^{\mathrm{n}+}\right)$ destabilize colloidal particles, i.e. trap colloidal particles and create flocs which can be easily removed from water by sedimentation or flotation (Kabdaşli et al. 2012; Pirkarami \& Olya 2017).

Some of the advantages of the EC process are: effluent contains less total dissolved solids compared to the other chemical processes, easy maintenance of the device, more efficient and faster degradation of organic matter compared to chemical coagulation, larger and more stable flocs are formed than those produced by chemical coagulation, it is not necessary to control the $\mathrm{pH}$ of the water, except in extreme cases, no chemicals are required, reduces residue, it can process multiple pollutants which can easily be removed, operating costs are much lower compared to most conventional technologies, the device is smaller and simpler than the coagulation device so it can be used as decentralized process and if the solar panels are used, the device can be used as a batch process in rural areas that don't have access to the electricity for processing the smaller quantities of wastewater (Vepsäläinen, 2012; Kuokkanen et al. 2013; Marriaga-Cabarales \& Machuca-Martínez 2014; Hakizimana et al. 2017).

However, some of the EC disadvantages are: in some countries, the use of electricity may be expensive, possible passivation of anode due to the oxygen presence and the deposition on the cathodes (can be overcomed by switching the electrode poles), the electrodes need to be regularly replaced which increases the maintenance costs, the high conductivity of the wastewater is required, the high concentrations of iron and aluminum need to be removed from the effluent, in some cases, the gelatinous hydroxides may be dissolved in water, it is not effective for the removal of the soluble substances such as sugars, organic acids, solvents, phenols, alcohol and similar (Vepsäläinen 2012; Kuokkanen et al. 2013; Marriaga-Cabarales \& Machuca-Martínez 2014; Hakizimana et al. 2017).

\section{APPLICATION OF ELECTROCOAGULATION FOR WATER CONDITIONING}

Water health parameters for human consumption are determined by the Ordinance on conformity parameters, analytical methods, monitoring and drinking water safety plans, and keeping register of legal entities which provide public water supply (Official Gazette 125/17). The aim of monitoring these parameters is to protect human health from the adverse impact of any contamination of water intended for human consumption and to ensure its health. According to the (Official Gazette 125/17), drinking water should be free of color, taste and smell. Maximum permissible concentrations of E. coli, iron, arsenic, manganese, ammonia, color, smell and turbidity, according to the (Official Gazette 125/17), are shown in Table 1.

Table 1. Chemical and indicator parameters

\begin{tabular}{|c|c|c|}
\hline PARAMETER & UNIT & $\begin{array}{c}\text { MAXIMUM PERMISSIBLE } \\
\text { CONCENTRATIONS }\end{array}$ \\
\hline Ammonia & $\mathrm{mg} / \mathrm{l}$ & 0.50 \\
\hline Arsenic & $\mu \mathrm{g} / \mathrm{l}$ & 10 \\
\hline Escherichia coli & E. coli/100 ml & 200 \\
\hline Iron & $\mu \mathrm{g} / \mathrm{l}$ & 50 \\
\hline Manganese & $\mu \mathrm{g} / \mathrm{l}$ & 20 \\
\hline Color & $\mathrm{mg} / \mathrm{PtCo}$ & - \\
\hline Smell & $/$ & 4 \\
\hline Turbidity & $\mathrm{NTU}$ & \\
\hline
\end{tabular}

\subsection{Removal of E. coli}

Microbiological contamination of water can be effectively counteracted by disinfection measures. Disinfection is the last stage of water preparation for the purpose of eliminating or decreasing the number of microorganisms in it. Mostly, chemical disinfection uses chlorine, chlorine dioxide or ozone. However, water disinfection is, most often, just one step in the water treatment and is often combined with other chemical processes (Andrija Stampar Teaching Institute of Public Health 2017). The examples in Table 2 show that EC has very high efficiency of $E$. coli removal. It can be noticed that $30 \mathrm{~min}$ is enough for complete $E$. coli removal with $\mathrm{Al}$ electrodes. 
Table 2. Recent applications of EC for E. coli removal

\begin{tabular}{|c|c|c|c|c|}
\hline VOLUME TREATED & $\begin{array}{c}\text { OPTIMAL } \\
\text { OPERATIVE } \\
\text { PARAMETERS }\end{array}$ & \% REMOVAL & $\begin{array}{l}\text { OPERATING } \\
\operatorname{COSTS}\left[€ / \mathbf{m}^{3}\right]\end{array}$ & REFERENCE \\
\hline 0.51 & $\begin{array}{c}\text { Al electrodes; } \\
\text { Electrode distance: } 5 \\
\text { cm; } 12 \mathrm{~V} \text {; treatment } \\
\text { time } 30 \text { min }\end{array}$ & 100 & - & Ghernaout et al. (2008) \\
\hline 11 & $\begin{array}{c}\text { Al electrodes; } \\
\text { Electrode distance: } 2 \\
\text { cm; } 30 \mathrm{~V} ; 22 \mathrm{~A} ; \\
\text { treatment time: } 30 \\
\text { min } \\
\end{array}$ & 99.8 & - & Ricordel et al. (2014) \\
\hline
\end{tabular}

\subsection{Iron removal}

The presence of iron in drinking water is not directly harmful to human health, but problems with discoloration, turbidity and unpleasant taste occur (Doggaz et al. 2018). There are several methods for removal of iron from drinking water, but aeration and separation are the most common methods (Gosh 2007). Some of the recent applications of EC for iron removal are shown in Table 3. Most commonly Al electrodes or their combinations with other materials are used. Also, the increase of current density influences the treatment efficiency and shortens the electrolysis time.

Table 3. Recent applications of EC for iron removal

\begin{tabular}{|c|c|c|c|c|}
\hline $\begin{array}{r}\text { VOLUME } \\
\text { TREATED }\end{array}$ & $\begin{array}{c}\text { OPTIMAL } \\
\text { OPERATIVE } \\
\text { PARAMETERS }\end{array}$ & \% REMOVAL & $\begin{array}{l}\text { OPERATING } \\
\text { COSTS }\left[€ / \mathrm{m}^{3}\right]\end{array}$ & REFERENCE \\
\hline 31 & $\begin{array}{c}\text { Al electrodes; } \\
\text { Electrode distance: } \\
0.5 \mathrm{~cm} \text {; treatment } \\
\text { time } 35 \mathrm{~min}\end{array}$ & 99.2 & 5.35 & Gosh et al. (2007) \\
\hline 11 & $\begin{array}{c}\text { Mn anode, } \mathrm{Fe} \\
\text { cathode; } 6 \mathrm{~A} / \mathrm{m}^{2} ; \\
\text { treatment time: } 60 \\
\min \end{array}$ & 98.4 & - & Vasudevan et al. (2009a) \\
\hline 11 & $\begin{array}{c}\mathrm{Al} \text { anode, } \mathrm{SS} \\
\text { cathode; } 6 \mathrm{~A} / \mathrm{m}^{2} ; \\
\text { treatment time: } 60 \\
\text { min; } \mathrm{pH} 6.5\end{array}$ & 98.8 & - & Vasudevan et al. (2009b) \\
\hline 2.21 & $\begin{array}{c}\text { Al electrodes; } \\
\text { Electrode distance: } \\
0.5 \mathrm{~cm} ; 15 \mathrm{~A} / \mathrm{m}^{2} ; \\
\text { treatment time: } 20 \\
\text { min; } \mathrm{pH} 6\end{array}$ & 98.5 & 0.20 & Hashim et al. (2017) \\
\hline
\end{tabular}

\subsection{Arsenic removal}

Among several investigated technologies for removal of arsenic from drinking water, most common are ionexchange, precipitation, coagulation/adsorption and membrane treatment systems. Although these processes produce high quality water, they require expensive resins, replaceable adsorption media and chemicals (Alferness 2016). It can be noticed that EC is a very efficient method for arsenic removal (Table 4). Total arsenic removal can be achieved under less than $30 \mathrm{~min}$ with Fe electrodes at an inter-distance of about $1 \mathrm{~cm}$. Applied voltage should be around 12-15 V. 
Table 4. Recent applications of EC for arsenic removal

\begin{tabular}{|c|c|c|c|c|}
\hline $\begin{array}{r}\text { VOLUME } \\
\text { TREATED }\end{array}$ & $\begin{array}{c}\text { OPTIMAL } \\
\text { OPERATIVE } \\
\text { PARAMETERS } \\
\end{array}$ & \% REMOVAL & $\begin{array}{l}\text { OPERATING } \\
\operatorname{COSTS}\left[€ / \mathbf{m}^{3}\right]\end{array}$ & REFERENCE \\
\hline 11 & $\begin{array}{l}\text { Fe electrodes; Electrode } \\
\text { distance: } 2 \mathrm{~cm} ; 12 \mathrm{~V} ; \\
\text { treatment time } 30 \mathrm{~min} ; \\
\text { pH } 7\end{array}$ & 100 & - & Wan et al. (2011) \\
\hline 1.41 & $\begin{array}{l}\text { Fe electrodes; Electrode } \\
\text { distance: } 0.5 \mathrm{~cm} ; 0.54 \\
\mathrm{~mA} / \mathrm{cm}^{2} \text {; treatment time: } \\
30 \mathrm{~min} ; \mathrm{pH} 4\end{array}$ & 99.5 & - & Can et al. (2014) \\
\hline 201 & $\begin{array}{l}\text { Al electrodes; Electrode } \\
\text { distance: } 0.55 \mathrm{~cm} ; 5.5 \\
\mathrm{~mA} / \mathrm{cm}^{2} \text {; treatment time: } \\
15 \mathrm{~min}\end{array}$ & 92.2 & - & Flores et al. (2014) \\
\hline 101 & $\begin{array}{l}\text { Fe and } \mathrm{Al} \text { electrodes; } \\
\text { Electrode distance: } 1 \mathrm{~cm} \text {; } \\
6 \mathrm{~A} ; 15 \mathrm{~V} \text {; treatment } \\
\text { time: } 20 \mathrm{~min}\end{array}$ & 100 & - & Oreščanin et al. (2014) \\
\hline 13.21 & $\begin{array}{l}\text { SS electrodes; Electrode } \\
\text { distance: } 2.2 \mathrm{~cm} ; 6 \mathrm{~V} \text {; } \\
\text { treatment time: } 60 \mathrm{~min}\end{array}$ & 96.7 & 0.47 & Alferness et al. (2016) \\
\hline
\end{tabular}

\subsection{Manganese removal}

The presence of manganese and other metals in drinking water may be responsible for its coloration. Conventional methods for removing manganese include chemical precipitation, coagulation, flotation, ionexchange, oxidation/filtration, adsorption and membrane filtration (Alvarez-Bastida et al. 2018). Some of the recent applications of EC for manganese removal are shown in Table 5. Manganese removal efficiency varies from 50-100 \%, depending on the treatment time and applied voltage. It can be assumed that the optimal operative parameters are Fe electrodes, electrode distance of $2 \mathrm{~cm}, 90 \mathrm{~min}$ of treatment time, $\mathrm{pH} 7$ and current density of 15 $\mathrm{mA} / \mathrm{cm}^{2}$. Also, the addition of supporting electrolyte, such as $\mathrm{SO}_{4}{ }^{2-}$, helps to increase the removal efficiency. More research on manganese removal needs to be done, and until then, it is suggested to combine it with other water treatments.

Table 5. Recent applications of EC for manganese removal

\begin{tabular}{|c|c|c|c|c|}
\hline $\begin{array}{r}\text { VOLUME } \\
\text { TREATED } \\
\end{array}$ & $\begin{array}{c}\text { OPTIMAL OPERATIVE } \\
\text { PARAMETERS } \\
\end{array}$ & \% REMOVAL & $\begin{array}{l}\text { OPERATING } \\
\text { COSTS }\left[€ / \mathbf{m}^{3}\right] \\
\end{array}$ & REFERENCE \\
\hline 0.51 & $\begin{array}{l}\text { Fe electrodes; Electrode distance: } 2 \\
\text { cm; } 2 \text { A; treatment time } 90 \text { min; } \mathrm{pH} 6\end{array}$ & 99 & 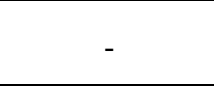 & Gatsios et al. (2015) \\
\hline 0.51 & $\begin{array}{l}\text { Fe electrodes; Electrode distance: } 2 \\
\mathrm{~cm} ; 10 \mathrm{~mA} / \mathrm{cm}^{2} ; \text { treatment time: } 60 \\
\mathrm{~min} ; \mathrm{pH} 7\end{array}$ & 50 & - & Xu et al. (2017) \\
\hline 0.51 & $\begin{array}{c}\text { Fe electrodes; Electrode distance: } 2 \\
\mathrm{~cm} ; 15 \mathrm{~mA} / \mathrm{cm}^{2} \text {; treatment time: } 120 \\
\mathrm{~min} ; \mathrm{pH} 7 \text {; addition of electrolyte: } 25 \\
\mathrm{mmol} / 1 \mathrm{SO}_{4}^{2-}\end{array}$ & 85.5 & - & Xu et al. (2018) \\
\hline
\end{tabular}

\subsection{Ammonia removal}

Ammonia in wastewater can originate from many sources such as fertilizer manufacturing, food processing, landfill leachate, agriculture, slaughterhouses and tanneries. Ammonia is considered as one of the most toxigenic contaminants, and high ammonia concentrations can cause eutrophication of rivers and lakes, thus disrupting the ecological balance. Till now, the main ammonia removal processes involved: air stripping, biological nitrification, denitrification, chemical treatment and selective ion exchange method (Desai et al. 2016). However, these methods are limited because of their cost, low efficiency and the use of toxic chemicals (Aoudj et al. 2017). Therefore, EC seems as an interesting solution for ammonia removal, and some results are shown in Table 6. According to results, 
EC is not effective for ammonia removal. The removal efficiency is less than $50 \%$ in all the mentioned research. Since it has been shown that EC is not effective enough to meet the standards determined by the Ordinance on conformity parameters, analytical methods, monitoring and drinking water safety plans, and keeping register of legal entities which provide public water supply (Official Gazette 125/17), it is suggested that EC needs to be combined with other water treatment processes.

Table 6. Recent applications of EC for ammonia removal

\begin{tabular}{|c|c|c|c|c|}
\hline VOLUME TREATED & $\begin{array}{c}\text { OPTIMAL } \\
\text { OPERATIVE } \\
\text { PARAMETERS } \\
\end{array}$ & \% REMOVAL & $\begin{array}{l}\text { OPERATING } \\
\text { COSTS }\left[€ / \mathrm{m}^{3}\right]\end{array}$ & REFERENCE \\
\hline 1.81 & $\begin{array}{l}\text { Al electrodes; } 3 \mathrm{~A} ; \\
\text { treatment time } 60 \mathrm{~min} \text {; } \\
\mathrm{pH} 8\end{array}$ & 24 & - & Son et al. (2017) \\
\hline 21 & $\begin{array}{c}\text { Al electrodes; } \\
\text { Electrode distance: } 2 \\
\text { cm; } 1.5 \mathrm{~A} ; 15 \mathrm{~V} ; \\
\text { treatment time: } 90 \mathrm{~min}\end{array}$ & 47 & - & Desai et al. (2016) \\
\hline 901 & $\begin{array}{c}\text { Al electrodes; } 150 \\
\mathrm{~A} / \mathrm{m}^{2} \text {; treatment time: } \\
120 \mathrm{~min} ; \mathrm{pH} 7\end{array}$ & 36 & 1.95 & Lončar et al. (2019) \\
\hline
\end{tabular}

\subsection{Color removal}

Colored water is not suitable nor for drinking nor for many industrial purposes such as food industry or cloth washing. There are two types of color in water, true and apparent color. True color is the result of soluble substances that cannot be isolated by filtration, and apparent color is the result of suspended solids and colloid particles that can be separated by filtration (Malakootian and Fatehizadeh 2010). It can be noticed that EC has high color removal efficiency $(97 \%$ ), but the choice of optimal operative parameters differs (Table 7). Therefore, more research on color removal by EC needs to be done.

Table 7. Recent applications of EC for color removal

\begin{tabular}{|c|c|c|c|c|}
\hline $\begin{array}{r}\text { VOLUME } \\
\text { TREATED }\end{array}$ & $\begin{array}{c}\text { OPTIMAL } \\
\text { OPERATIVE } \\
\text { PARAMETERS }\end{array}$ & \% REMOVAL & $\begin{array}{l}\text { OPERATING } \\
\text { COSTS }\left[€ / \mathbf{m}^{3}\right]\end{array}$ & REFERENCE \\
\hline 1.51 & $\begin{array}{c}\mathrm{A} 1 \text { electrodes; } 300 \\
\mathrm{~A} / \mathrm{m}^{2} ; \text { treatment time } \\
120 \text { min; } \mathrm{pH} 5.2 \\
\end{array}$ & 97.2 & - & Kara et al. (2013) \\
\hline 31 & $\begin{array}{c}\text { Fe electrodes; Electrode } \\
\text { distance: } 5 \mathrm{~cm} ; 2.07 \\
\mathrm{~mA} / \mathrm{cm}^{2} \text {; treatment } \\
\text { time: } 45 \mathrm{~min} ; \mathrm{pH} 7.6\end{array}$ & 97 & 0.26 & $\begin{array}{l}\text { Khansorthong and } \\
\text { Hunsom (2016) }\end{array}$ \\
\hline
\end{tabular}

\subsection{Turbidity removal}

Water turbidity is caused by suspended solids and colloidal particles of clay, sludge, fine organic matter, microorganisms and other. The precipitation of particles depends on their density and size. Particles with higher density precipitate due to gravity and smaller particles, especially ones whose density is similar as water density, such as bacteria and colloidal particles, don't precipitate, but remain suspended in water and need to generate larger flocs. Conventional treatments for turbidity removal have several disadvantages, such as the use of large amounts of chemicals and generating large amounts of sludge which causes disposal problems and the loss of water (Gulić 2003). It has been shown that EC is good for removing water turbidity (more than $95 \%$ ) and some results of previous research are shown in Table 8. According to previous research, optimal operative parameters very much differ. Since all mentioned types of the electrode material have high removal efficiency, their price can be a deciding factor. Suggested optimal operative parameters are Al electrodes, $2 \mathrm{~cm}$ of electrode distance, $20 \mathrm{~V}$ voltage and $40 \mathrm{~min}$ of treatment time. 
Table 8. Recent applications of EC for turbidity removal

\begin{tabular}{|c|c|c|c|c|}
\hline $\begin{array}{r}\text { VOLUME } \\
\text { TREATED } \\
\end{array}$ & $\begin{array}{c}\text { OPTIMAL OPERATIVE } \\
\text { PARAMETERS } \\
\end{array}$ & \% REMOVAL & $\begin{array}{l}\text { OPERATING } \\
\operatorname{COSTS}\left[€ / \mathbf{m}^{3}\right]\end{array}$ & REFERENCE \\
\hline 21 & $\begin{array}{c}\text { Fe electrodes; Electrode } \\
\text { distance: } 5 \mathrm{~cm} ; 5.62 \mathrm{~mA} / \mathrm{cm}^{2} \text {; } \\
\text { treatment time } 40 \mathrm{~min} ; \mathrm{pH} \\
5.2\end{array}$ & 95 & - & Ni'am et al. (2007) \\
\hline 31 & $\begin{array}{c}\text { Al electrodes; Electrode } \\
\text { distance: } 2 \mathrm{~cm} ; 20 \mathrm{~V} ; \\
\text { treatment time: } 10 \mathrm{~min}\end{array}$ & 97 & - & Rahmani (2008) \\
\hline 11 & $\begin{array}{c}\text { SS electrodes; Electrode } \\
\text { distance: } 2 \mathrm{~cm} ; 20 \mathrm{~V} ; \\
\text { treatment time } 180 \mathrm{~min} ; \mathrm{pH} 7\end{array}$ & 98 & - & $\begin{array}{l}\text { Adapureddy and Goel } \\
\text { (2012) }\end{array}$ \\
\hline 31 & $\begin{array}{c}\text { Al electrodes; Electrode } \\
\text { distance: } 2 \mathrm{~cm} ; 30 \mathrm{~V} ; \\
\text { treatment time } 25 \mathrm{~min} ; \mathrm{pH} 7\end{array}$ & 95 & 0.12 & Moosavirad (2017) \\
\hline
\end{tabular}

\section{ECONOMY ANALYSIS AND THE COMPARISON OF REMOVAL EFFICIENCY}

Economy analysis, along with the removal efficiency analysis, plays an important role in the selection of optimal water treatment. The economic factors that can influence this choice are chemicals, coagulation resins, membranes, electricity, work, maintenance, etc. Only few papers analyzed the cost of EC, and most of the experiments were conducted on small batch units (Vepsäläinen 2012). Therefore, only rough estimation and approximate cost comparison of EC and similar water treatments can be given. Operative costs of some previous research are shown in Tables 3-8, and cost and efficiency comparisons between EC and several water treatments are given in Figures 3-6.

The first comparison is for turbidity and Figure 3 shows that EC has higher removal efficiency than the combination of ultrafiltration/coagulation by $10 \%$. Also, operative costs of EC are lower than for the combination of ultrafiltration/coagulation by $0.20 € / \mathrm{m}^{3}$ (Figure 4). Therefore, it is justified to use EC for removal of turbidity.

\section{Turbidity removal efficiency [\%]}

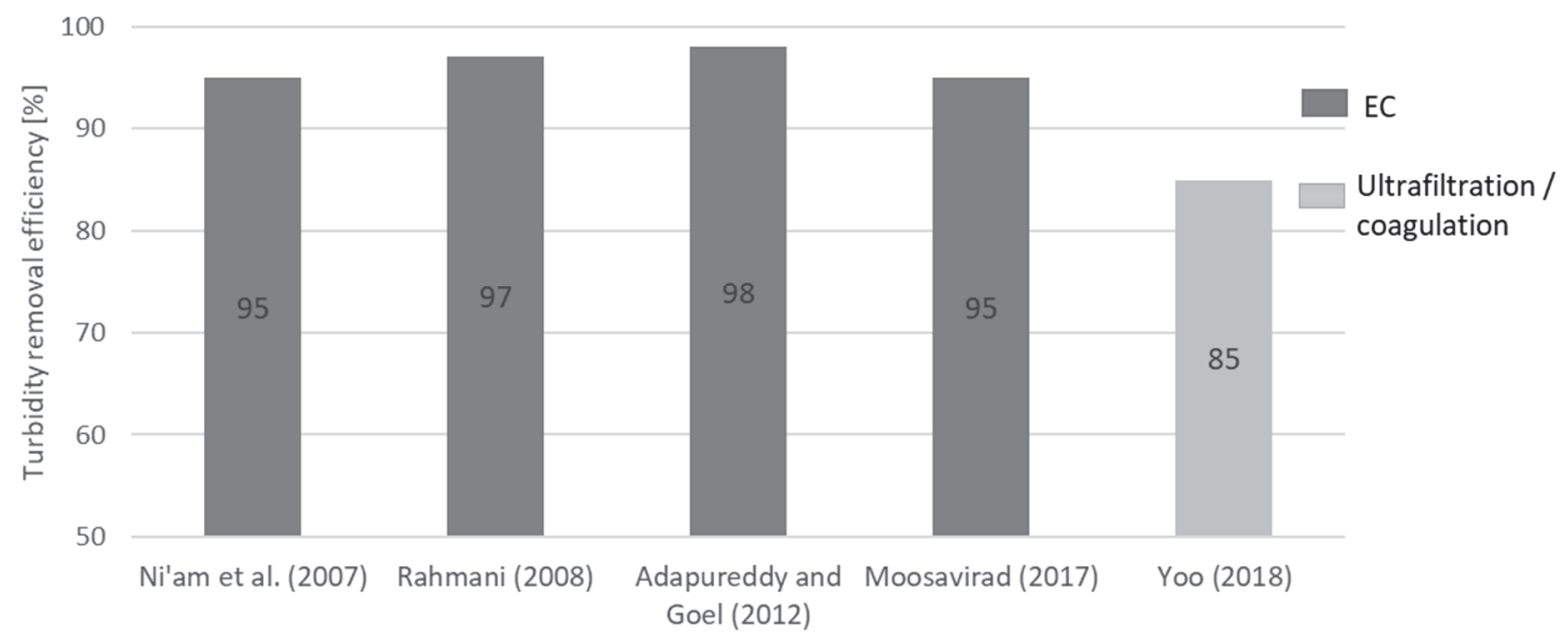

Figure 3. Comparison of turbidity removal efficiency 


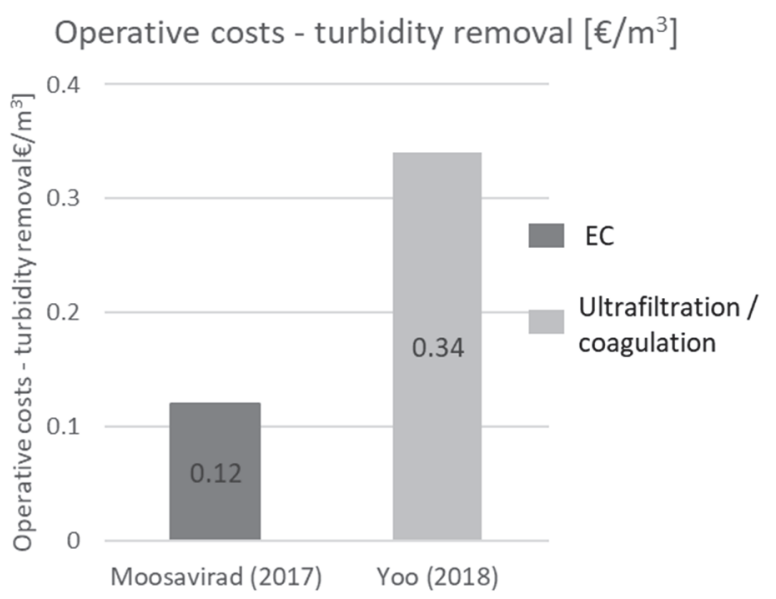

Figure 4. Comparison of operative costs for turbidity removal

The second comparison is for arsenic removal efficiency. Reverse osmosis and EC process both have very high removal efficiencies and similar operative costs (Figure 5 and Figure 6). But since more research was carried out on it, the advantage is given to reverse osmosis. It is noted that all studies were conducted on units with similar capacity.

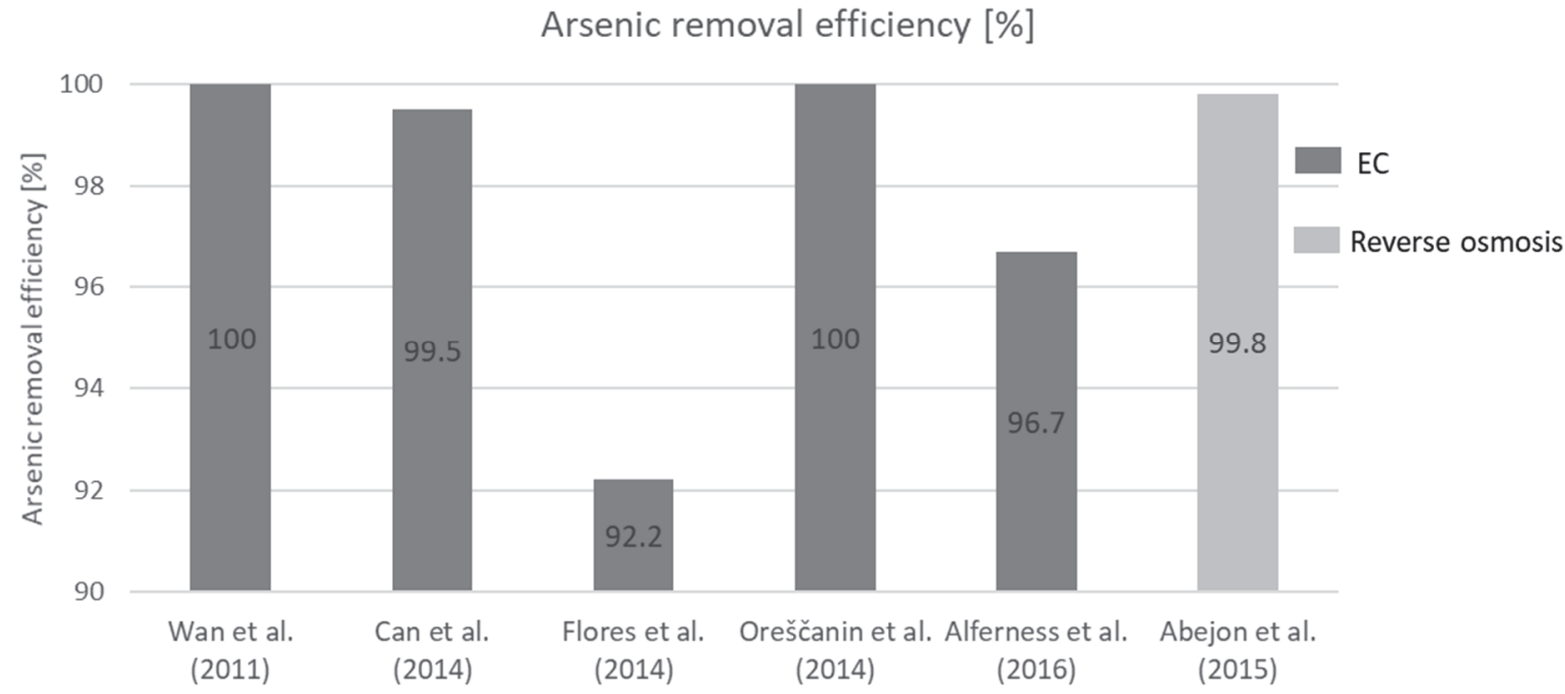

Figure 5. Comparison of arsenic removal efficiency

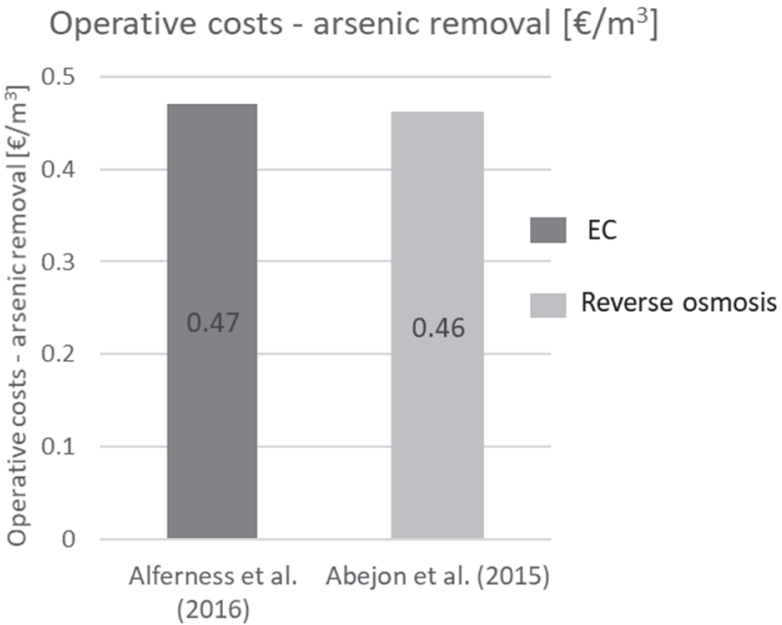

Figure 6. Comparison of operative costs for arsenic removal 


\subsection{Removal of Total Nitrogen on a full-scale electrocoagulation reactor}

A case study with Al electrodes was performed on a full-scale batch EC unit made from stainless steel, Figure 7. The unit has two rectangular chambers (tanks), whose dimensions are $0.80 \mathrm{~m} \times 0.55 \mathrm{~m} \times 1.10 \mathrm{~m}$. In the study, $90 \mathrm{~L}$ of water was used as the operating volume. The first tank is used for EC process, from which water can circulate (by pump) between two rectangular Fe, Al or SS electrode plates, while the second one is used as a settling tank. The total surface of Al electrodes was $0.063 \mathrm{~m}^{2}$ and the electrode distance was $0.5 \mathrm{~cm}$.

(a)

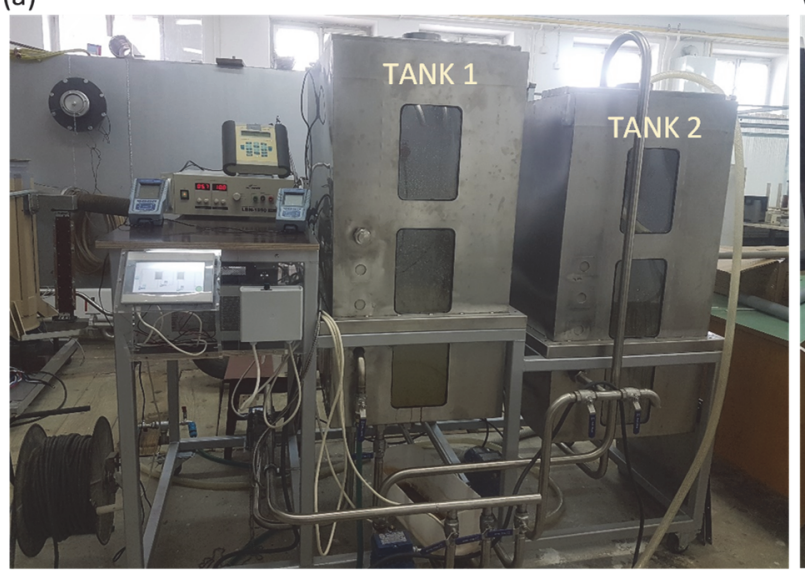

(b)

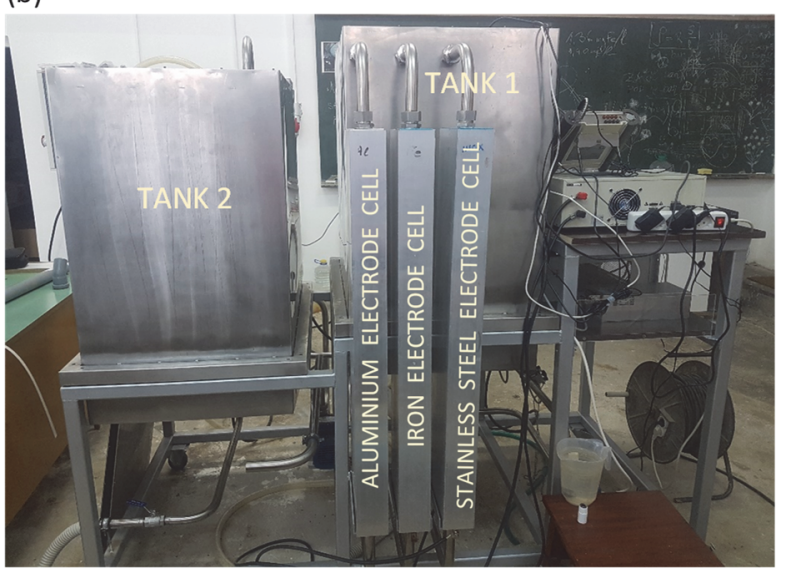

Figure 7. (a) The front and (b) the back of the EC unit

In the tank 1 (Figure 7), $100 \mathrm{~mL}$ of $25 \% \mathrm{NH}_{3}$ solution was mixed with $90 \mathrm{~L}$ of drinking water from public water supply system in order to obtain Total Nitrogen (TN) concentration just over $200 \mathrm{mg} / \mathrm{L}$. Also, $180 \mathrm{~g} \mathrm{of} \mathrm{NaCl}$ was added in order to increase the solution conductivity and obtain its concentration around $2 \mathrm{~g} / \mathrm{L}$. Everything was mixed for several minutes. The initial $\mathrm{pH}$ was 9.8 and total treatment time was $240 \mathrm{~min}$. Water samples were taken before the beginning of the treatment, at every $60 \mathrm{~min}$, and at the end of the process. TN concentrations were measured with NANOCOLOR 500D (by Eutech) Test 0-88 (TNb 220). Flow $(Q=0.03 \mathrm{~L} / \mathrm{s})$ was measured with ultrasonic water meter FLUXUS F601 (by Flexim), and the current was maintained approximately constant at 12 A by the MC Power LBN-1990 lab power supply. After $240 \mathrm{~min}$, TN was decreased to $63 \mathrm{mg} / \mathrm{L}$, corresponding to removal efficiency of $69.7 \%$ (Figure 8, Table 9).

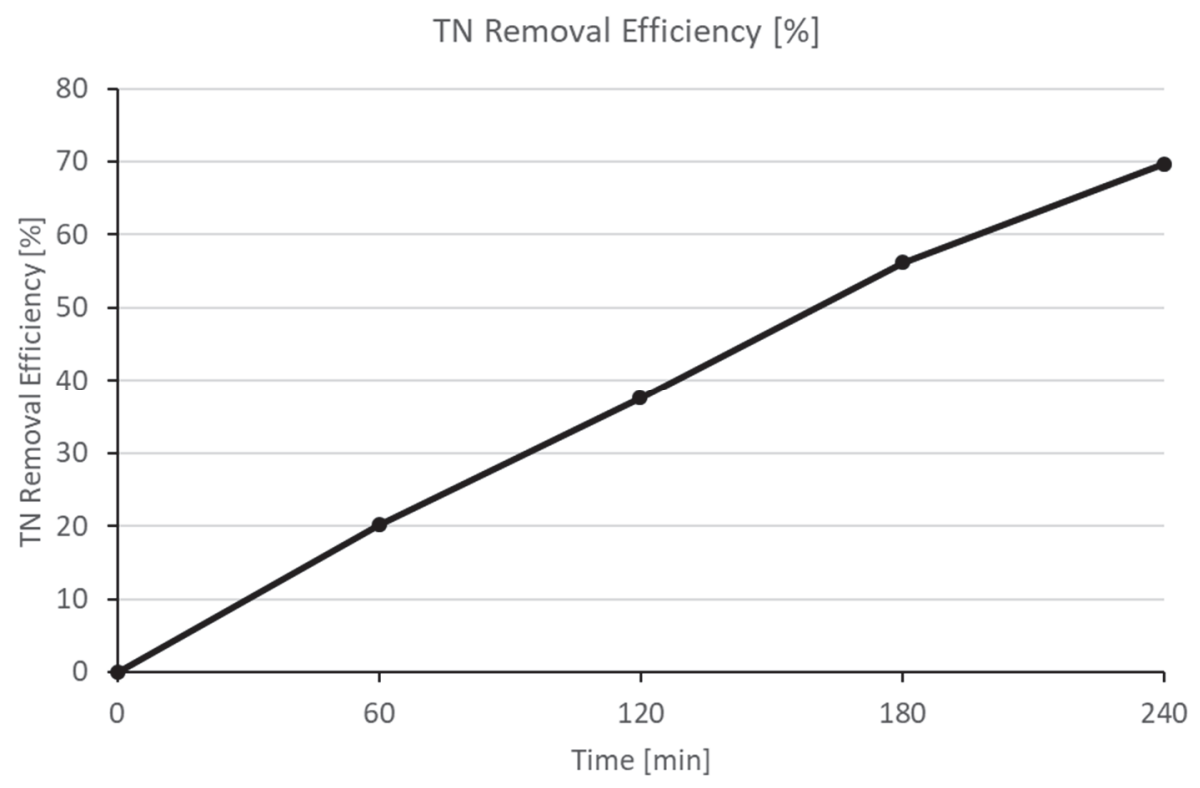

Figure 8. TN removal efficiency

According to Figure 8, a linear trend of TN removal can be noticed, approximately $33 \mathrm{mg} / \mathrm{L}$ per hour. In comparison with some previous results (Posavčić et al., 2018), it is assumed that flow significantly affects the removal efficiency and is better that the water runs slower through the electrodes because there is more time for the formation of Al hydroxides. 
Further, the operating costs are determined for this case (Table 9). An assessment of the operational costs of the EC process is given regarding energy cost, consisting of electricity and pump (power) costs, and material (electrodes) cost according to Equation 3:

$$
\text { Operating costs }=a\left(C_{\text {electricity }}+C_{\text {pump }}\right)+b C_{\text {material }}
$$

where: $C_{\text {electricty }}$ is electrical energy cost of $1 \mathrm{~m}^{3}$ of treated water $\left(\mathrm{kWh} / \mathrm{m}^{3}\right), C_{\text {pump }}$ is the energy cost of the pump for $1 \mathrm{~m}^{3}$ of treated water $\left(\mathrm{kWh} / \mathrm{m}^{3}\right)$ and $C_{\text {material }}\left(\mathrm{kg} \mathrm{Al} / \mathrm{m}^{3}\right)$ is the cost of the electrode material used in $1 \mathrm{~m}^{3}$ of the treated water. $a$ is the average electricity price of $0.13 € / \mathrm{kWh}$ (according to the national tariff models), and $b$ is the average market price of aluminum given as $1.54 € / \mathrm{kg}$. After $240 \mathrm{~min}$, total operational costs were $7.60 € / \mathrm{m}^{3}$.

Table 9. TN removal efficiency (\%) and operating costs for energy (electricity and pump) and material (electrode)

\begin{tabular}{|c|c|c|c|c|c|c|}
\hline $\begin{array}{c}\text { TIME } \\
{[\mathbf{m i n}]}\end{array}$ & $\begin{array}{c}\text { TN } \\
{[\mathbf{m g} / \mathbf{L}]}\end{array}$ & \% REMOVAL & $\begin{array}{c}\mathbf{C}_{\text {electricity }} \\
{\left[\mathbf{k W h} / \mathbf{m}^{3}\right]}\end{array}$ & $\begin{array}{c}\mathbf{C}_{\text {pump }} \\
{\left[\mathbf{k W h} / \mathbf{m}^{3}\right]}\end{array}$ & $\begin{array}{c}\mathbf{C}_{\text {electrode }} \\
{\left[\mathbf{k g} / \mathbf{m}^{3}\right]}\end{array}$ & $\begin{array}{c}\text { OPERATING } \\
\mathbf{C O S T S} \\
{\left[\mathbf{\epsilon} / \mathbf{m}^{3}\right]}\end{array}$ \\
\hline 0 & 208 & - & - & - & - & - \\
\hline 60 & 166 & 20.19 & 8.00 & 5.56 & 0.09 & 1.90 \\
\hline 120 & 130 & 37.50 & 16.00 & 11.11 & 0.18 & 3.80 \\
\hline 180 & 91 & 56.25 & 24.00 & 16.67 & 0.27 & 5.70 \\
\hline 240 & 63 & 69.70 & 32.00 & 22.22 & 0.36 & 7.60 \\
\hline
\end{tabular}

\section{CONCLUSION}

According to previous research, EC is suitable for removal of E. coli, iron, arsenic, color and turbidity. However, in cases with manganese and ammonia, it has been shown that EC is not effective enough to meet the standards determined by the Ordinance on conformity parameters, analytical methods, monitoring and drinking water safety plans, and keeping register of legal entities which provide public water supply (Official Gazette 125/17) and needs to be combined with other water treatment processes.

Generally, most of the previous research were conducted on "small-scale" units, i.e. small capacity devices (up to $10 \mathrm{~L}$ ), where received results (operative costs and operative parameters), are not applicable in real conditions. Therefore, in order to obtain more credible results, more research on pilot devices need to be done.

In this paper, a case study is also presented. Observed linear change indicates that the EC process for TN removal, with specified reactor setup, can be modelled with a simple linear rule with the average removal rate of $33 \mathrm{mg} / \mathrm{L} \cdot \mathrm{h}$ for $0.03 \mathrm{~L} / \mathrm{s}$ flow rate.

Linear change can be attributed to the approximately constant current that was maintained at $12 \mathrm{~A}$. Also, what was not previously reported is that during the study the current was constantly slowly decreasing. Approximately every 15 minutes current dropped for $1 \mathrm{~A}$. In order to keep the current constant, the voltage was increased accordingly.

\section{REFERENCES}

Abejón A, Garea A, Irabien A (2015) Arsenic removal from drinking water by reverse osmosis: Minimization of costs and energy consumption. Sep Purif Technol 144: 46-53. doi: 10.1016/j.seppur.2015.02.017

Adapureddy SM, Goel S (2012) Optimizing Electrocoagulation of Drinking Water for Turbidity Removal in a Batch Reactor, 2012 International Conference on Environmental Science and Technology, Singapur, 30, 97-102

Alferness MK, Casares AR, Chiesa SC (2016) Evaluation of a Point-of-Use Electrocoagulation System for Arsenic Removal. International Journal for Service Learning in Engineering, Humanitarian Engineering and Social Entrepreneurship 11: 51-66. doi: 10.24908/ijsle.v11i1.6326

Alvarez-Bastida C, Martinez-Miranda V, Solache-Rios M, Linares Hernandez I, Teutli-Sequeira A, Vazquez Mejia G (2018) Drinking water characterization and removal of manganese. Removal of manganese from water. J. Environ. Chem. Eng 6: 2119-2125. doi: 10.1016/j.jece.2018.03.019

Andrija Stampar Teaching Institute of Public Health (2017): Dezinfekcija vode - kloriranje i hiperkloriranje. Available via http://www.stampar.hr/hr/dezinfekcija-vode-kloriranje-i-hiperkloriranje. Cited 12 Mar 2019

Aoudj S, Khelifa A, Drouiche N (2017) Removal of fluoride, SDS, ammonia and turbidity from semiconductor wastewater by combined electrocoagulation-electroflotation. Chemosphere, 180: 379-387. doi: 10.1016/j.chemosphere.2017.04.045 
Can BZ, Boncukcuoğlu R, Yilmaz AE, Fil BA (2014) Effect of some operational parameters on the Arsenic removal by electrocoagulation using iron electrodes. J Environ Health Sci 12: 1-10. doi: 10.1186/2052-336X-1295

Chen G, Hung Y (2007) Electrochemical Wastewater Treatment Process. In: Wang L.K., Hung YT., Shammas N.K. (eds) Advanced Physicochemical Treatment Technologies. Handbook of Environmental Engineering, vol 5. Humana Press. doi: 10.1007/978-1-59745-173-4_2

Council Directive 98/83/EC of 3 November 1998 on the quality of water intended for human consumption. In Official Journal L 330: 32-54. Available via https://eur-lex.europa.eu/legalcontent/EN/TXT/?uri=CELEX\%3A31998L0083. Cited 10 Jan 2019

Croatian Institute of Public Health (2018) Izvještaj o zdravstvenoj ispravnosti vode za ljudsku potrošnju u Republici Hrvatskoj za 2017. godinu. Available via https:/www.hzjz.hr/wp-content/uploads/2018/06/IzvjestajRH-voda-za-ljudsku-potrosnju-2017_v1.pdf. Cited Jan 2019

Desai RN, Vyas DS, Patel SM, Mehta H (2016) Removal of Ammonical Nitrogen by Electrocoagulation Method. IJARIIE 2: 505-509. doi: 16.0415/IJARIIE-2160

Doggaz A, Attour A, Le Page Mostefa A, Tlil, M, Lapicque F (2018) Iron removal from waters by electrocoagulation: Investigations of the various physicochemical phenomena involved. Sep Purif Technol 203: 217-225. doi: 10.1016/j.seppur.2018.04.045

Flores OJ, Nava JL, Carreno G (2014) Arsenic Removal from Groundwater by Electrocoagulation Process in a Filter-Press-Type FM01-LC Reactor. Int J Electrochem Sci 9: 6658-6667.

Gardić V (2007) Primena elektrohemijskih metoda za prečišćavanje otpadnih voda. Deo I - elektrodepozicija i elektrokoagulacija. Zaštita materijala 48: 49-58. doi: $628.31 .087 .4 / .5=861$

Gatsios E, Hahladakis JN, Gidarakos E (2015) Optimization of electrocoagulation (EC) process for the purification of a real industrial wastewater from toxic metals. J Environ Manage 154: 117-127. doi: 10.1016/j.jenvman.2015.02.018

Ghernaout D, Badis A, Kellil A, Ghernaout B (2008) Application of electrocoagulation in Escherichia coli culture and two surface waters. Desalination 219: 118-125. doi: 10.1016/j.desal.2007.05.010

Ghosh D, Solanski H, Purkait MK (2007) Removal of Fe (II) from tap water by electrocoagulation technique. J Hazard Mater 155: 135-143. doi: 10.1016/j.jhazmat.2007.11.042

Gulić I (2003) Kondicioniranje vode. Hrvatski savez građevinskih inženjera, Zagreb

Hakizimana JN, Gourich B, Chafi M, Stiriba Y, Vial C, Drogui P, Naja J (2017) Electrocoagulation process in water treatment: A review of electrocoagulation modeling approaches. Desalination 404: 1-21. doi: 10.1016/j.desal.2016.10.011

Hashim KS, Shaw A, Al Khaddar R, Pedrola MO, Phipps D (2017) Iron removal, energy consumption and operating cost of electrocoagulation of drinking water using a new flow column reactor. J Environ Manage 189: 98-108. doi: 10.1016/j.jenvman.2016.12.035

Kabdaşlı I, Arslan-Alaton I, Ölmez-Hancı T, Tünay O (2012) Electrocoagulation applications for industrial wastewaters: a critical review. Environ Technol Rev 1: 2-45. doi: 10.1080/21622515.2012.715390

Kara S, Gürbulak E, Eyvaz M, Yüksel E (2013) Treatment of winery wastewater by electrocoagulation process. Desalin Water Treat 51: 5421-5429. doi: 10.1080/19443994.2013.770223

Khansorthong S, Hunsom M (2009) Remediation of wastewater from pulp and paper mill industry by the electrochemical technique. Chem Eng J 151: 228-234. doi: 10.1016/j.cej.2009.02.038

Kuokkanen V, Kuokkanen T, Rämö J, Lassi U (2013) Recent Applications of Electrocoagulation in Treatment of Water and Wastewater - A Review. Green and Sustainable Chemistry 81: 89-121. doi: 10.4236/gsc.2013.32013

Lončar G, Halkijević I, Posavčić H, Ban I (2019) Primjena elektrokoagulacijskog uređaja s ciljem smanjenja koncentracije amonijaka. Hrvatske vode 108: 129-142

Malakootian A, Fatehizadeh A (2014) Color removal from water by coagulation/caustic soda and lime. Iran J Environ Health Sci Eng 2010: 7, 267-272

Marriaga-Cabarales N, Machuca-Martínez F, (2014) Fundamentals of electrocoagulation. In: PeraltaHernández, J.M., Rodrigo-Rodrigo M.A. and Martínez-Huitle (Eds) Evaluation of Electrochemical Reactors as a New Way to Environmental Protection. C.A., 1-16

Moussa DT, El-Naas MH, Nasser M, Al-Marri MJ (2017) A comprehensive review of electrocoagulation for water treatment: Potentials and challenges. J Environ Manage 186: 24-41. doi: 10.1016/j.jenvman.2016.10.032

Moosavirad SM (2017) Treatment and operation cost analysis of greywater by electrocoagulation and comparison with coagulation process in mining areas. Sep Sci Technol 52: 1742-1750. doi: 10.1080/01496395.2016.1274761

Ni'am MF, Othman F, Sohaili J (2007) Removal of COD and turbidity to improve wastewater quality using electrocoagulation technique. Malaysian Journal of Analytical Sciences 11: 198-205.

Ordinance on conformity parameters, analytical methods, monitoring and drinking water safety plans, and keeping register of legal entities which provide public water supply. In Official Gazette 125/17. Available via https://narodne-novine.nn.hr/clanci/sluzbeni/2017_12_125_2848.html. Cited 12 Mar 2019 
Oreščanin V, Kollar R, Nađ K, Halkijević I, Kuspilić M, Findri Gustek Š (2014) Removal of arsenic, phosphates and ammonia from well water using electrochemical/chemical methods and advanced oxidation: a pilot plant approach. J Environ Sci Health A Tox Hazard Subst Environ Eng 49: 1007-1014. doi: 10.1080/10934529.2014.894843

Pirkarami A, Olya ME (2017) Removal of dye from industrial wastewater with an emphasis on improving economic efficiency and degradation mechanism. J Saudi Chem Soc 21: 1176-1182. doi: 10.1016/j.jscs.2013.12.008

Posavčić H, Halkijević I, Kuspilić M (2018) A review of Electrocoagulation Process Parameters for Industrial Wastewater Treatment. In: Conference proceedings New Technologies in Water Sector 7-12 May 2018, Zagreb, Croatia, pp. 541-548

Rahmani AR (2008) Removal of dye from industrial wastewater with an emphasis on improving economic efficiency and degradation mechanism. J Res Health Sci 8: 18-24.

Ricordel C, Miramon C, Hadijev D, Darchen A (2014) Investigations of the mechanism and efficiency of bacteria abatement during electrocoagulation using aluminum electrode. Desalin Water Treat 52: 5380-5389. doi: 10.1080/19443994.2013.807474

Shammas NK, Pouet M, Grasmick A (2010) Wastewater Treatment by Electrocoagulation-Flotation. In: Wang, L (Ed) Flotation Technology, Springer: New York, NY, SAD, pp. 199-220. doi: 10.1007/978-1-60327$133-2$

Son L, Khai L, Ha N, Linh D, Anh D (2017) Electrocoagulation for ammonium removal in Nam Son landfill leachate. VNU Journal of Science: Earth and Environmental Sciences 33: 71-77. doi: 10.25073/25881094/vnuees.4047

Vasudevan S, Lakshmi J, Sozhan G (2009a) Studies on the Removal of iron from Drinking water by electrocoagulation. Clean 37: 45-51. doi: 10.1002/clen.200800175

Vasudevan S, Jeganathan J, Lakshmi J, Sozhan G (2009b) Removal of iron from drinking water by electrocoagulation: Adsorption and kinetics studies. Korean J. Chem. Eng 26: 1058-1064. doi: 10.1007/s11814009-0176-9

Vepsäläinen M (2012) Electrocoagulation in the treatment of industrial waters and wastewaters. Doctoral thesis

Vuković Ž (2017) Vodoopskrba vodom i odvodnja I - web script, Faculty of Civil Engineering, University of Zagreb, Zagreb. Available via http://www.grad.unizg.hr/predmet/ovio1_b. Cited Dec 2018

Wan W, Pepping TJ, Banerji T, Chaudhari S, Giammar DE (2011) Effects of water chemistry on arsenic removal from drinking water by electrocoagulation. Water Res 45: 384-392. doi: 10.1016/j.watres.2010.08.016

Xu L, Cao G, Xu X, Liu S, Duan Z, He C, Wang Y, Huang Q (2017) Simultaneous removal of cadmium, zinc and manganese using electrocoagulation: Influence of operating parameters and electrolyte nature. J Environ Manage 204: 394-403. doi: 10.1016/j.jenvman.2017.09.020

Xu L, Xu X, Cao G, Liu S, Duan Z, Song S, Song M, Zhang M (2018) Optimization and assessment of Fe electrocoagulation for the removal of potentially toxic metals from real smelting wastewater. J Environ Manage 218: 129-138. doi: 10.1016/j.jenvman.2018.04.049

Yoo SS (2018) Operating Cost Reduction of In-line Coagulation/Ultrafiltration Membrane Process Attributed to Coagulation Condition Optimization for Irreversible Fouling Control. Water 10: 1076-1093. doi: $10.3390 /$ w 10081076 